\title{
POPULATION DENSITY AND FOOD PREFERENCE OF THE LAND SNAIL, Monacha cantiana (MONTAGU) TO CUCURBIT VEGETABLE CROPS AND USING PLANT EXTRACTS FOR ITS CONTROL \\ Shahawy, Wafaa A. \\ Harmful Animals Department, Plant Protection Research Institute, Agricultural Research Center
}

\section{ABSTRACT}

An experiment was carried out at Farag El-Shamy, El-Riad region, Kafr El-Sheikh Governorate during two successive seasons; 2012 and 2013 to study the population density, food preference and evaluation of some plant extracts on Monacha cantiana on some cucurbit vegetables. Data showed that the most attractive vegetable crop to snail was water melon (120.36 and 122.27 snails) while the cucumber was the least preferred with (63.64 and 64.55) snails during two seasons, respectively. The highest population density of M.cantaina were $51.75,47.5,43.25,41.5$ and 40.25 snail $/ \mathrm{m}^{2}$ while the least number were $15.75,9.5,10.0,8.75$ and 7.0 snail $/ \mathrm{m}^{2}$ on water melon, squash, snake melon melon and cucumber in two seasons respectively. Geranium extract exhibits the highest toxic effect $(84.5 \%)$ reduction while the lowest was neem oil $(56.0 \%)$ reduction on water melon.

\section{INTRODUCTION}

Land snails are considered one of the most destructive agricultural pests causing economic damage to a wide variety of plants including horticulture and field crops. In Egypt, land snails have been located mostly in the northern Governorates of Delta region, attacking various crops causing great damage to the soft vegetative parts of the plants. Land snails are dangerous agricultural pests causing great damage to field and vegetable crops in addition to horticultural vegetation such as citrus, guava, pear and date palm as well as ornamental plants, as the plant parts (Shahawy, 2005). The land snail, Monacha cantiana (Montagu) became an important agriculture pest causing a great damage to crops in deferent localities in Egypt as previously mentioned. It was recorded with relatively high population density on major economic crops at Kafr El-Sheikh Governorate.

Using mollusicides in high concentration has a toxic effect on man and livestock and cause environmental pollution, El-Wakil and Radwan (1991). In recent years, many researchers tried to find new mechanical, ecological and biological control methods that are safer, cheaper, and more readily available.

An experiment was carried out at Farag El-Shamy, El-Riad region, Kafr El-Sheikh Governorate during two successive seasons; 2012 and 2013. Aim of the work to study the population density, food preference and nonpreference and evaluation of some plant extracts on the most common snail, Monacha canaiana (Montagu) at this region infesting the following five plant species: melon, Cucumis melo L.; cucumber, Cucumis sativum L.; snake 
melon, Cucumis sativaus L.; water melon, Citrullus lanatus (Thunb) and squash, Cucurbita pepo (pumpkin).

\section{MATERIALS AND METHODS}

\section{Preference and non-preference of snail, Monacha cantiana (Montagu)} to five cucurbite species:

An experiment was carried out at Farag El-Shamy, El-Riad region, Kafr El-Sheikh Governorate under field conditions during the two successive seasons; 2012 and 2013 to study the preference and non-preference of the snail, M. cantiana infesting branches and leaves of melon, Cucumis melo L.; cucumber, Cucumis sativum L.; snake melon, Cucumis sativaus L.; water melon, Citrullus lanatus (Thunb) and squash, Cucurbita pepo (pumpkin). An area of half feddan $\left(2100 \mathrm{~m}^{2}\right)$ was prepared, and then seedlings of the plant species were transplanted in alternative rows at $35 \mathrm{~cm}$ spaces between them and width of $175 \mathrm{~cm}$ between rows in the plots from April $1^{\text {st }}$ during the two seasons. Weekly samples were taken randomly from each plant species on April $15^{\text {th }}$ to Jun. $26^{\text {th }}$. Each sample was obtained from one $\mathrm{m}^{2}$ and replicated four times.

2. Evaluation of some aqueous and oil plant extracts on the infestation with Monacha cantiana (Montagu) snail on water melon:

\subsection{Collection and preparation of the plant extracts:}

Five aromatic plant species (sweet basil, geranium, spearmint peppermint and clove) were collected from the Farm of Sakha Agricultural Research Station, Kafr El-Sheikh. The plants were dried naturally on laboratory benches at room temperature for 7 days, to become crisp dry. Further drying was practiced in the oven at $40{ }^{\circ} \mathrm{C}$ for $24 \mathrm{hrs}$, and then the plant parts were crushed to fine powder using a laboratory grinder.

Table (1): Aromatic plant species used to control Monacha cantiana.

\begin{tabular}{|c|c|c|c|c|}
\hline $\begin{array}{l}\text { Arabic } \\
\text { name }\end{array}$ & English name & Scientific name & Part used & Family \\
\hline 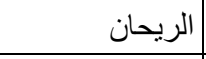 & Sweet basil & Ocimum basilicum L. & Leaves & Lamiaceae \\
\hline 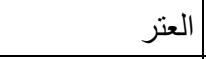 & Geranium & Pelargonium graveolens L. & Leaves & Geraniaceae \\
\hline | النعناع البلدى & Spearmint & Mentha viridis $\mathrm{L}$. & Leaves & Lamiaceae \\
\hline النعناع الفلفلي & Peppermint & Mentha piperita L. & Leaves & Lamiaceae \\
\hline 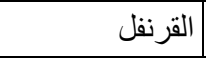 & Clove & Eugenia aromatic (E.a) & Flower buds & Myrtaceae \\
\hline
\end{tabular}

\section{2. Preparation of crude extracts:}

Dried plant powders were extracted according to Freedman et al. (1979), $250 \mathrm{~g}$ of each plant sample were soaked in $750 \mathrm{ml}$ of polar solvent (ethyl alcohol) and non- polar solvent (n-hexane) in a large conical flask for $72 \mathrm{hrs}$. with shaking for $3 \mathrm{hrs}$. The contents of the flask were filtered through anhydrous sodium sulphate. The extracts were concentrated by removing the solvent on water bath at $40{ }^{\circ} \mathrm{C}$ to obtain the crude extract. The obtained 
extracts were weighed and dissolved in an appropriate volume of pure acetone, and kept in the refrigerator for assaying.

\section{3. Preparation of plant aqueous extracts:}

Plant parts used were soaked in three volumes of water for $72 \mathrm{hrs}$. and then screened through muslin cloth (El-Samahy, 2002).

\section{Preparing the field experiment:}

A field experiment was conducted at Farag El-Shamy, El-Riad. An area of one feddan $\left(4200 \mathrm{~m}^{2}\right)$ was divided into 48 plots (each plot about 87.5 $\mathrm{m}^{2} /$ replicate) in a randomized complete block design. Seedlings of melon, cucumber, snake melon, water melon and squash were transplanted at a space of $35 \mathrm{~cm}$ between plants and a width of $175 \mathrm{~cm}$ between rows in the plots on April $1^{\text {st }}$ in 2012 and second season 2013. Extracts and oils aromatic plant species were applied with concentration of $0.5 \%$. while Metaldehyed 5 $\%$ molluscicide were applied $2 \mathrm{kgm} /$ feddan on April $29^{\text {th }}$ using atomizer of 2 liters to complete coverage of treated water melon plants. Snails were directly counted before treatment on leaves, branches and on soil surface from each plant in one meter. Also these samples were taken 1,3,5,7 and 10 days post treatment. The reduction in snail population due to treatments was calculated according to Henderson and Telton (1955).

Duncan's multiple range test (1955) at $5 \%$ level was used to reveal the significance among the means of larvae on the evaluated plant species.

\section{RESULTS AND DISCUSSION}

\section{Population density of Monacha cantiana (Montagu) on cucurbit} crops:

The population density of snail, $M$. cantiana was counted on the leaves, branches and soil surface of five cucurbit crops Table (2). The first observation was carried out on April $15^{\text {th }}$ in 2012 and 2013 seasons. The snail, $M$. cantiana was recorded on all vegetable crops. The level of infestation varied from one crop to another.

\subsection{Water melon:}

During 2012 season, population density of the snail appeared in two peaks, on April $29^{\text {th }}$ and May $20^{\text {th }}$ Table (2). The highest mean number of snail was 51.75 snails $/ \mathrm{m}^{2}$ on April $29^{\text {th }}$. However, the lowest mean number was 15.75 snails $/ \mathrm{m}^{2}$ on the last season.

Population density of snails during 2013 season, showed approximately a similar trend as that in 2012 season.

1.2. Squash:

During 2012 season, population fluctuation of snail, M. cantiana numbers displayed into two peaks, April $29^{\text {th }}$ and May $20^{\text {th }}$. The highest mean number of the snail stages were $47.50 \mathrm{snail} / \mathrm{m}^{2}$ on April $29^{\text {th }}$, however, the lowest mean number of snail stages was $9.50 \mathrm{snail} / \mathrm{m}^{2}$ on June $25^{\text {th }}$. Population fluctuation of snail, M. cantiana during 2013 season, showed a similar trend to that of 2012 season Table (2).

Table (2): Population density of snail, Monacha cantiana on five plant species during 2012 and 2013 seasons. 


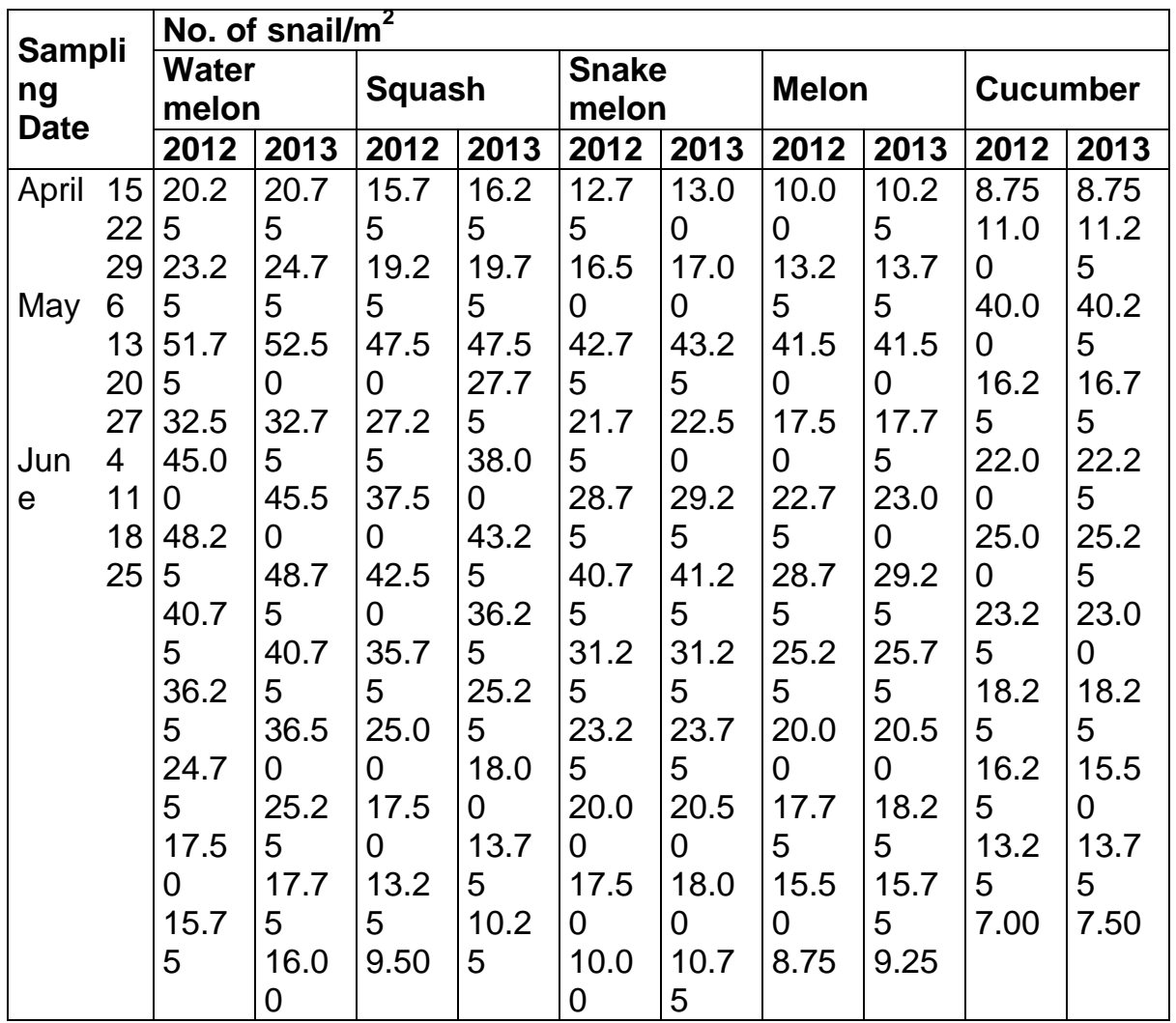

\subsection{Snake melon:}

Data presented in Table (2) display the population density of snail, $M$. cantiana stages during 2012 and 2013 seasons. Results showed two peaks; on April $29^{\text {th }}$ and on May $20^{\text {th }}$. The highest mean number of snail stages was $42.75 \mathrm{snail} / \mathrm{m}^{2}$ on April $29^{\text {th }}$, while the lowest mean number was 10.00 snail $/ \mathrm{m}^{2}$ on the last sample. Population density of snail stages during 2013 season, showed approximately a similar trend to that of 2012 season Table (2).

\subsection{Melon:}

During 2012 season, population density of snail, M. cantiana stages recorded two peaks, on April $29^{\text {th }}$ and May $20^{\text {th }}$. The highest mean number of snail stages was $41.50 \mathrm{snail} / \mathrm{m}^{2}$ on April $29^{\text {th }}$ however, on the lowest mean number $8.75 \mathrm{snail} / \mathrm{m}^{2}$ on the last season Table (2). Population density of snail stages during 2013 season showed a similar trend to that of 2012 season.

\subsection{Cucumber:}

The highest mean number of snail stages was 40.00 snail $/ \mathrm{m}^{2}$ during first season while in the second season; the mean number of snail stages was $40.25 \mathrm{snails} / \mathrm{m}^{2}$ on April $29^{\text {th }}$. However, the lowest mean number of snail stages was 7.00 snails $/ \mathrm{m}^{2}$ on last season Tables (2).

El-Okda et al. (1989) showed that the infestation of most of land snails occurred during May till November on fences, while it was present 
through the year on the inner plantations. The authors added also that the highest population density was noticed in the neglected and weedy orchards.

Also, Shahawy (1998) recorded the highest snail numbers on lettuce and clover in April. The population of the snail was greatly reduced on lettuce and clover during December and January.

2. Food preference of Monacha cantiana to five vegetable plant species:

The results in Fig. (1) show the preference of snail stages to five vegetable crops during the two seasons. Statistical analysis showed that the highest mean number of snail stages during the two seasons were 120.36 and 122.27 snails, on water melon, respectively followed by squash plant. However, the lowest mean numbers of snail stages were recorded on cucumber and melon with (63.64 - 64.55) and (71.72 - 72.72) snails during two seasons, respectively.

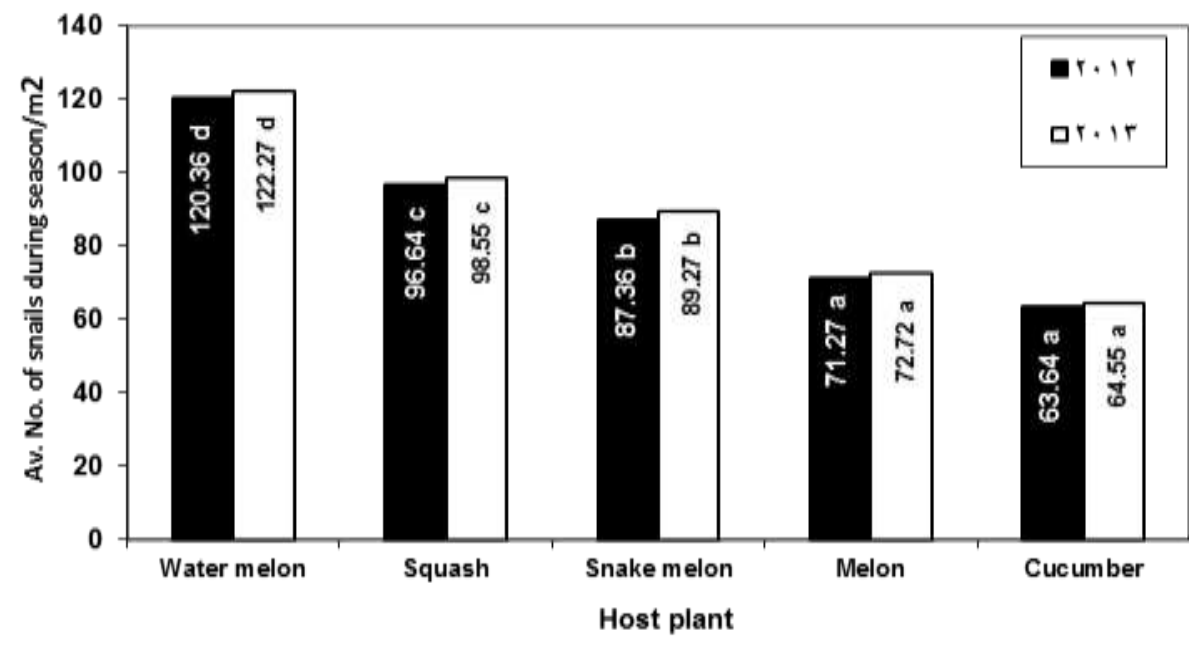

Fig. (1): Preference and non-preference of snail, Monacha cantiana to five vegetable plant species during 2012 and 2013 seasons.

3. Effect of some plant extracts on Monacha cantiana stages on water melon:

Data presented in Tables ( 3 and 4 ) showed that the initial and residual effect of plant extracts, clove oil, spearmint oil, peppermint oil, sweet basil oil, geranium oil, jojoba oil, neem oil, and aqueous extracts (ae) of sweet basil, geranium, peppermint, spearmint and clove against snails infesting water melon during 2012 season.

Data showed that the initial activity of geranium extract was higher than the other tested compounds. While, the initial and toxicities of neem oil was the least. Residual activities of the tested substances were estimated as shown in Table (3). Geranium extract, sweet basil, metaldehyed and clove extract were the most potent compounds, while, neem oil and jojoba oils were less active. 
Sharshir et al. (1996) used ground seeds of eight plants, black pepper, caraway, coriander, anise, cumin, tooth pick, capsicum and damsissa in order to evaluate their toxicity against the land snail, $M$. catniana under laboratory conditions. Results indicated that pure ethanolic extract of caraway and coriander gave high mortality to M. catniana, while cumin and tooth pick were the least effective.

Shahawy (1998) examined 14 plant extracts against $M$. cantiana. The plants were belonging to six families; Umbelliferae, Composite, Solanaceae, Lamiaceae, Piperaceae and Geraniaceae. Results showed that caraway extract was the most effective against snail, followed by parsley, damsissa and yarrow.

Table (3): Initial and residual effect of extracts and oils of aromatic plants against Monacha cantiana on Water melon during 2012 season.

\begin{tabular}{|c|c|c|c|c|c|c|c|c|c|c|c|c|c|}
\hline \multirow{3}{*}{ Treatment } & \multirow{3}{*}{\begin{tabular}{|l|} 
No. of \\
snails \\
before \\
treatmen \\
$t$
\end{tabular}} & \multicolumn{10}{|c|}{ Period after treated by day } & \multicolumn{2}{|c|}{ General } \\
\hline & & \multicolumn{2}{|l|}{1} & \multicolumn{2}{|l|}{3} & \multicolumn{2}{|l|}{5} & \multicolumn{2}{|l|}{7} & \multicolumn{2}{|l|}{10} & \multirow[b]{2}{*}{ No. } & \multirow[b]{2}{*}{ R.\% } \\
\hline & & No. & $\mathbf{R} \%$ & No. & $\mathbf{R} \%$ & No. & $\mathbf{R} \%$ & No & $\mathbf{R} \%$ & No & $\mathbf{R} \%$ & & \\
\hline Control & 203 & 208 & 00.0 & 218 & 00.0 & 223 & 00.0 & \begin{tabular}{|l|}
23 \\
4 \\
\end{tabular} & 00.0 & \begin{tabular}{|l|}
24 \\
4 \\
\end{tabular} & 00.0 & 1127 & $00.0 \mathrm{a}$ \\
\hline $\begin{array}{l}\text { Metaldehyed } \\
\text { molluscicid }\end{array}$ & 206 & 73 & 65.4 & 55 & 75.1 & 41 & 81.9 & 37 & 84.4 & 57 & 77.0 & 263 & $.0 \mathrm{~d}$ \\
\hline \begin{tabular}{|l} 
Clove oil \\
\end{tabular} & 202 & 99 & 52.2 & 77 & 64.5 & 69 & 68.9 & 61 & 73.8 & 35 & 85.6 & 341 & $69.6 \mathrm{c}$ \\
\hline Spearmint oil & 204 & 107 & 48.8 & 98 & 55.7 & 85 & 62.1 & 77 & 67.3 & 66 & 73.1 & 433 & $61.8 \mathrm{~b}$ \\
\hline \begin{tabular}{|l} 
Peppermint oil \\
\end{tabular} & 201 & 100 & 51.4 & 95 & 56.0 & 82 & 62.9 & 75 & 67.6 & 60 & 75.2 & 412 & 63.1 c \\
\hline Sweet basil oil & 200 & 97 & 52.7 & 75 & 65.1 & 62 & 71.8 & 55 & 76.1 & 31 & 87.1 & 320 & $71.2 \mathrm{c}$ \\
\hline Geranium oil & 203 & 91 & 56.3 & 65 & 70.2 & 52 & 76.7 & 37 & 84.2 & 33 & 86.5 & 278 & $75.3 \mathrm{~d}$ \\
\hline Jojoba oil & 206 & 117 & 44.6 & 101 & 54.3 & 95 & 58.0 & 85 & 64.2 & 72 & 70.9 & 470 & $58.9 \mathrm{~b}$ \\
\hline \begin{tabular}{|l|} 
Neem oil \\
\end{tabular} & 203 & 125 & 39.9 & 105 & 51.8 & 96 & 57.0 & 92 & 60.7 & 78 & 68.0 & 496 & $56.0 \mathrm{~b}$ \\
\hline Sweet basil (ae) & 205 & 86 & 59.1 & 48 & 78.2 & 42 & 81.4 & 32 & 86.5 & 18 & 92.7 & 226 & 80.1de \\
\hline Geranium (ae) & 200 & 74 & 63.9 & 40 & 81.4 & 32 & 85.4 & 15 & 93.5 & 11 & 95.4 & 172 & $84.5 \mathrm{e}$ \\
\hline Peppermint (ae) & 206 & 92 & $\begin{array}{l}56.4 \\
1\end{array}$ & 64 & 71.1 & 50 & 77.9 & 44 & 81.5 & 26 & 89.5 & 276 & $75.9 \mathrm{~d}$ \\
\hline Spea & 203 & 98 & 52.9 & 73 & 66.5 & 59 & 73.5 & 52 & 77.8 & 33 & 86.5 & 315 & $72.1 \mathrm{~cd}$ \\
\hline Clove (ae) & 200 & 98 & 52.2 & 53 & 75.3 & 46 & 79.1 & 39 & 83.1 & 23 & 90.4 & 259 & $76.7 \mathrm{~d}$ \\
\hline
\end{tabular}

(ae) aqueous extract

Means followed by a common letter are not significantly different at the $5 \%$ level by DMRT

REFERANCES

Duncan, D. B. (1955). Multiple range and multiple F-test. Biometrics, 11: 1 124.

El-Okda, M. M. K.; M. M. Emara and A. H. Hanafei (1989). Preliminary observation on land mollusca infestion fencing plants. Agric. Res. Rev., 10 (2): 387-396. 
El-Samahy, M. F. M. (2002). Studies on rice stem borer, Chilo agamemnon Bles. M. Sc. Thesis, Fac. Agric., Kafr El-Sheikh, Tanta Univ., 91 pp.

El-Wakil, H. B. and M. R. Radwan (1991). Biochemical studies on the terrestrial snails, Eobania vermiculata (Muller) treated with some pesticides. J. Environ. Sci., Health, B26 (596): 479-489.

Freedman, B., I. J. Nowak; W. F. Kowak; E. C. Berry and W. D. Guthri (1979). A bioassay for plant derived pest control agents using the European corn . J. Econ. Entomol. 72, 541-545.

Henderson, C. F. and E.w. Telton (1955). Test with acaricides against the brown wheat mite. J. Econ. Entmol., 48: 157-161.

Shahawy, W. A. (1998). Ecological studies and some control methods for land snail Monacha cantiana (Montagu) at Kafr El-Sheikh Governorate. M. Sc. Thesis, Fac. Agric. Kafr El-Sheikh, Tanta Univ., $86 \mathrm{pp}$.

Shahawy, W. A. (2005). Biological and histological studies on the land snails Moacha cantiana (Montagu) and its control at Kafr El-Sheikh region. Ph. D. Thesis, Fac. Agric. Kafr El-Sheikh, Tanta Univ., $128 \mathrm{pp}$.

Sharshir, F.A. F.A.M. Ahmad and M.A. Okka (1996). Plant extracts as a mean for controlling the land snail Monacha cantiana (Montagu) under laboratory conditions. J Agric. Res. Tanta Univ. 22(3): 400-406.

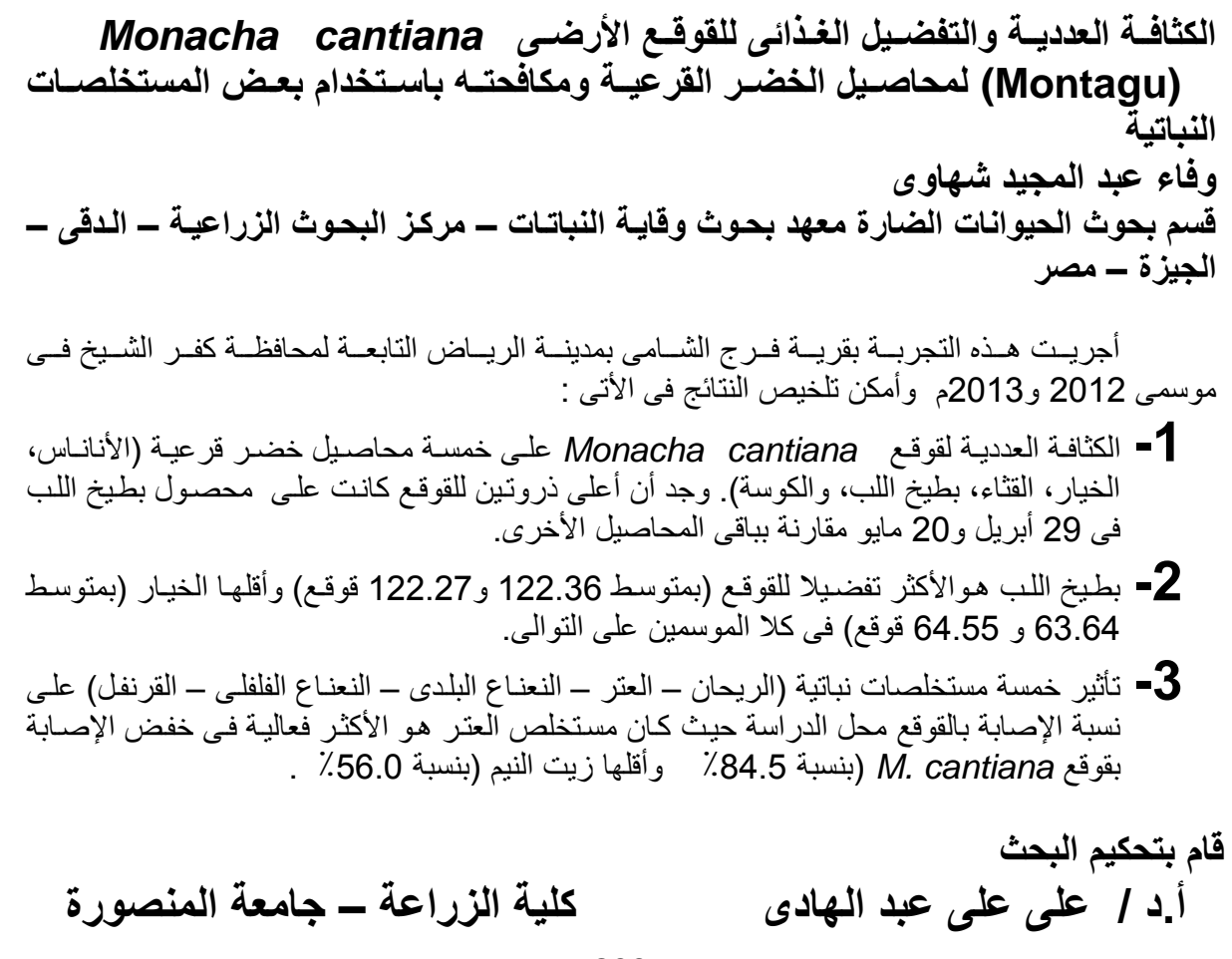


Shahawy, Wafaa A.

مركز البحوث الزراعية

أ.د / محمد محمد مرتضى 